\title{
\begin{tabular}{|c|c|}
\hline CAPITAL & $\begin{array}{c}\text { JURNAL EKONOMI DAN MANAJEMEN } \\
\text { P-ISSN: 2598-9022/ E-ISSN: 2598-9618 } \\
\text { Available at: http://e-journal.unipma.ac.id/index.php/capital }\end{array}$ \\
\hline
\end{tabular}
}

\section{Tantangan UKM Menghadapi Pandemi Covid-19: Pengaruh Kepemimpinan dan Pelatihan terhadap Kinerja}

\author{
Mei Rani Amalia \\ Fakultas Ekonomi dan Bisnis, Universitas Pancasakti Tegal \\ email: meraniamalia@gmail.com
}

\begin{abstract}
SMES have a very important role, so it can be said that SMES are the backbone of the Indonesian economy. BPS Data informs that about $99 \%$ of existing business units are SMES capable of absorbing manpower about $96.3 \%$ of the amount of productive workforce available. But since the outbreak of Covid-19 struck Indonesia from the end of December 2019, the business of SMES is one of the most experienced sectors, such as sales that go down, difficult to obtain raw materials, the disbanding of production and capital are some of the perceived effects of SMES during the pandemic. To be able to continue to maintain its performance, it takes good cooperation from all parties from government, private, and community participation. This research is conducted with the aim to know the impact of training and leadership on the performance of SME Kab. Tegal during the Covid-19 pandemic. The study took 100 random samples and data collection was conducted through observations, interviews, and questionnaires. Data analysis methods use multiple linear regression analyses. The results showed that partial training had no significant effect on performance, while leadership had a significant influence on MSME performance. Simultaneously the training and leadership significantly affect the performance of SME Kab. Tegal during the Covid-19 pandemic. Training to the SMES will help improve the performance during the pandemic.
\end{abstract}

Keywords: SMES, leadership, training, pandemic covid-19, performance

\section{Abstrak}

UKM mempunyai peran yang sangat penting, sehingga dapat dikatakan bahwa UKM merupakan tulang punggung bagi perekonomian Indonesia. Data BPS menginformasikan bahwa sekitar 99\% unit usaha yang ada adalah UKM yang mampu menyerap tenaga kerja sekitar 96,3\% dari jumlah tenaga kerja produktif yang tersedia. Namun sejak wabah covid-19 melanda Indonesia mulai akhir Desember 2019, bisnis UKM merupakan salah satu sektor yang paling merasakan dampaknya, seperti penjualan yang turun, sulit mendapatkan bahan baku, terhambatnya produksi dan permodalan merupakan beberapa dampak yang dirasakan UKM selama pandemi. Untuk dapat terus mempertahankan kinerjanya, diperlukan kerja sama yang baik dari semua pihak mulai dari pemerintah, swasta, dan peran serta masyarakat. Penelitian ini dilakukan dengan tujuan untuk mengetahui pengaruh pelatihan dan kepemimpinan terhadap kinerja UKM Kab. Tegal selama masa pandemi covid-19. Penelitian ini mengambil 100 sampel secara acak dan pengumpulan data dilakukan melalui observasi, wawancara, dan kuesioner. Metode analisis data menggunakan analisis regresi linear berganda. Hasil penelitian menunjukkan bahwa secara parsial pelatihan tidak berpengaruh secara signifikan terhadap kinerja, sedangkan kepemimpinan mempunyai pengaruh yang signifikan terhadap kinerja UKM. Secara simultan pelatihan dan kepemimpinan berpengaruh secara signifikan terhadap kinerja UKM Kab. Tegal selama masa pandemi Covid19. Pemberian pelatihan kepada para pelaku UKM dirasa akan membantu meningkatkan kinerja selama pandemi,

Kata Kunci: UKM, pelatihan, kepemimpinan, pandemi covid-19, kinerja. 


\section{A. PENDAHULUAN}

Kemajuan teknologi memang banyak membawa dampak positif bagi perusahaan. Perusahaan dapat lebih efektif dan efisien dalam menjalankan kegiatan operasionalnya sehingga laba yang diperoleh dapat lebih maksimal. Namun demikian, ada dampak negatif yang ditimbulkan oleh majunya teknologi terutama di Indonesia yang mempunyai jumlah penduduk yang padat, yaitu semakin terbatasnya kesempatan kerja. Terbatasnya lapangan pekerjaan yang tersedia saat ini telah meningkatkan jumlah pengangguran, mengingat angkatan kerja akan selalu bertambah setiap tahunnya. Hal ini kemudian membangkitkan kesadaran akan pentingnya peran usaha kecil dan menengah (UKM) sebagai tulang punggung perekonomian. Menurut Rahmana, 2008UKM yang ada di Indonesia dapat bertahan di situasi yang sulit seperti misalnya pada saat krisis ekonomi melanda pada tahun 1997 - 1998 disebabkan oleh beberapa hal: 1) Sebagian besar UKM menghasilkan barang konsumsi (consumer goods), 2) Mayoritas UKM mengandalkan non-banking financing untuk pendanaan usahanya, 3) Umumnya UKM melakukan spesialisasi produk yang ketat yaitu hanya memproduksi barang dan jasa tertentu saja, 4) UKM terbentuk karena banyaknya pemutusan hubungan kerja di sektor formal. Namun demikian, munculnya wabah virus covid-19 pada akhir Desember 2019 telah memukul perekonomian Indonesia termasuk UKM.

Untuk menghadapi badai yang secara tiba-tiba datang memukul usaha di berbagai lini ini termasuk UKM, kita tidak bisa hanya pasrah dan menunggu saja sampai badai pergi, apalagi bagi pemimpin atau pemilik usaha, harus mempunyai kemampuan yang lebih baik dalam mengendalikan usahanya supaya bisa terus bertahan. Pemimpin usaha harus mempunyai jiwa kepemimpinan yang mumpuni terutama dalam menghadapi situasi yang sulit, seperti adanya wabah covid-19 ini. Kemudian untuk meningkatkan pengetahuan dan ketrampilannya diperlukan juga pelatihan untuk meningkatkan sehingga dapat mempertahankan atau bahkan mengembangkan usahanya di tengah pandemi yang sedang merebak. Selain itu, pembinaan dan pelatihan untuk UKM juga perlu semakin mendapatkan perhatian dari pemerintah mengingat peran besar mereka dalam mengembangkan perekonomian negara .

Menurut data Badan Pusat Statistik Kabupaten Tegal, jumlah UKM di Kabupaten Tegal cukup banyak yaitu sekitar 140.042 dengan 17 jenis bidang usaha seperti kerajinan, logam, makanan, minuman, dan usaha lainnya. Sebenarnya ini merupakan 
potensi yang besar dalam menggerakkan ekonomi kerakyatan, namun selama pandemi covid-19 ini mulai merebak, banyak UKM di Kabupaten Tegal yang kesulitan dalam mempertahankan usahanya. Kepala Dinas Perdagangan, Koperasi, dan UKM Kabupaten Tegal pun tidak menampik bahwa selama pandemi ini kondisi UKM di Kabupaten Tegal sedikit lesu, hampir sama ketika krisis ekonomi tahun 1998 silam. Dalam situasi yang demikian, sebenarnya pemerintah daerah Kabupaten Tegal sudah bertindak cepat, melalui surat edaran bupati yang salah satunya berisi anjuran bagi para ASN untuk membeli produk UKM Kabupaten Tegal rata-rata Rp 100.000,- atau minimal Rp 25.000,- per bulan. Kebijakan lain yang dibuat pemerintah Kabupaten Tegal selama pandemi ini adalah mengenai penangguhan angsuran pinjaman yang ditujukan ke perbankan tentang relaksasi kredit bagi UMKM sehingga usaha mereka dapat terus berjalan dan dapat menghindari adanya Pemutusan Hubungan Kerja (PHK).

Pemerintah daerah sudah berusaha membantu meringankan beban yang dihadapi oleh UKM selama pandemi ini, namun tentu saja faktor internal, terutama gaya kepemimpinan dari pelaku UKM itu sendiri lah yang lebih banyak menentukan usahanya dapat bertahan atau tidak. Sikap profesionalitas dan pola pikir kewirausahaan yang mandiri serta berdaya saing global merupakan tuntutan bagi para pemilik UKM saat ini supaya dapat lebih bertahan terutama ketika menghadapi situasi yang sulit. Pelaku UKM juga dituntut untuk dapat mengelola sumber daya manusia yang ada, salah satunya dengan memperhatikan kepuasan kerjanya sehingga diharapkan mereka akan dapat memberikan kinerja yang baik.

Pergerseran pasar pun harus diperhatikan mengingat kecenderungan perilaku masyarakat sekarang lebih memilih pasar online dibandingkan pasar offline. Perubahan strategi pemasaran selama pandemi yang memaksa masyarakat untuk tidak beraktivitas ke luar rumah semakin dituntut cepat untuk dilakukakan pemilik UKM, sehingga bagi mereka belum memahami digital marketing perlu mendapatkan pelatihan sehingga usahanya dapat terus bertahan. Pelaku UKM harus sudah siap dan mulai akrab dengan teknologi komunikasi dan informatika yang berkembang pesat seperti sekarang ini sehingga tidak mudah tergerus dalam persaingan yang semakin ketat.

Berdasarkan latar belakang masalah tersebut, maka dapat disusun pertanyaan penelitian berikut: Bagaimana pengaruh kepemimipinan dan pelatihan terhadap kinerja UKM Kab. Tegal? 


\section{B. TINJAUAN PUSTAKA}

Kinerja merupakan hal yang sangat berpengaruh terhadap perkembangan hidup dan matinya organisasi termasuk UKM. Namun, tanpa adanya tolak ukur keberhasilan, kinerja akan sulit untuk diukur. Menurut Gibson (2003) kinerja merupakan keberhasilan dalam melaksanakan tugas serta kemampuan untuk mencapai tujuan yang telah ditetapkan. Kinerja dinyatakan baik dan sukses jika tujuan yang sudah ditetapkan sebelumnya dapat tercapai. Pada umumnya UKM di Indonesia masih sangat lemah dalam kegiatan industri manufaktur dibandingkan dengan UKM-UKM dari negara lain seperti Taiwan, Korea, dan Jepang yang berhasil menjadi sub kontrak dari Usaha Besar. (Tambunan, 2015). Kinerja UKM terutama di Indonesia dapat dilihat dari beberapa aspek, yaitu 1) nilai tambah, 2) unit usaha, tenaga kerja, dan produktivitas, 3) nilai ekspor. (Rahmana, 2008 dalam Masuci 2010). Menurut Teori Mathis, ada tiga faktor utama yang mempengaruhi kinerja, yaitu: 1) kemampuan, yang meliputi bakat, minat, dan faktor pribadi; 2) usaha yang dilakukan meliputi motivasi, etika kerja, kehadiran, dan rancangan tugas; 3) dukungan organisasi meliputi pelatihan dan pengembangan, peralatan dan teknologi, standar kerja, manajemen, serta rekan kerja. (Primajaya, 2006:12 dalam Endrawati, 2017).

Kepemimpinan merupakan suatu konsep yang dapat dikatakan abstrak, tetapi hasilnya dapat terlihat atau nyata, sehingga terkadang kepemimpinan tidak hanya dipandang sebagai ilmu tetapi juga seni. Menurut Goetsch dan Davis (1994:92) kepemimpinan merupakan kemampuan untuk membangkitkan semangat orang lain agar bersedia dan memiliki tanggung jawab total terhadap usaha mencapai atau melampaui tujuan organisasi. Menurut Yukl (2001) kepemimpinan adalah faktor utama dalam menggerakkan, mengarahkan, dan mengkoordinasikan faktor-faktor lainnya dalam suatu organisasi atau perusahaan. Kepimimpinan di sini dikaitkan dengan ciri-ciri individual, perilaku, pengaruhnya terhadap orang lain, pola interaksi, peran, tempatnya di posisi administratif serta persepsi orang lain mengenai keabsahannya. Terdapat beberapa jenis kepemimpinan, diantaranya gaya kepemimpinan karismatik, transaksional, transformasional, situasional, partisipatif, dan autentik. (Robbins dan Judge, 2017). Pimpinan UKM mungkin tidak akan menjadi pemimpin dengan gaya kepemimpinan tersebut terus menerus, karena masing-masing memiliki fungsinya sendiri. Namun demikian, seorang pimpinan akan sukses dan dihormati oleh karyawan jika dapat menggunakan gaya kepemimpinan sesuai dengan kondisi yang ada. Kriteria yang 
digunakan untuk mengukur efektivitas kepemimpinan menurut Bower \& Seashore dalam dalam Hadari Nawawi (2003:111) yaitu “1) adanya dukungan pimpinan yang mampu meningkatkan harga diri dan perasaan anggota organisasi; 2) kemudahan interaksi; 3) kemudahan dalam bekerja."

Tidak semua pelaku UKM memahami akan hal-hal yang dibutuhkan untuk usahanya, sehingga di sini diperlukan peran dari berbagai pihak untuk memberikan pelatihan yang dapat meningkatkan keterampilan atau kinerja UKM, mengingat besarnya peran UKM dalam perekonomian negara. Pelatihan dapat dibagi menjadi empat kategori, yaitu: 1) keterampilan dasar, meliputi keterampilan membaca, menulis, dan matematika; 2) keterampilan teknis, meliputi peningkatan keterampilan kerja karena adanya teknologi dan desain struktur organisasi yang baru; 3) keterampilan pemecahan masalah, meliputi penajaman logika, pertimbangan, dan keterampilan dalam mendefinisikan masalah serta menganalisis alternatif dan memilih solusi; 4) keterampilan interpersonal, meliputi kemampuan berinteraksi secara efektif dengan rekan kerja atau atasan; 5) pelatihan kesopanan, meliputi pembentukan karakter menjadi pribadi yang sopan dan pemahaman akan efek negatif dari ketidaksopanan dalam lingkungan kerja yang dapat berakibat fatal; 6) Pelatihan etika, meliputi pemaparan yang lebih tinggi mengenai kode etik organisasional sehingga dapat bertindak lebih etis dan meningkatkan rasa tanggung jawab. (Robbins dan Judge, 2017).

Beberapa penelitian, membuktikan bahwa gaya kepemimpinan dan pelatihan mempunyai pengaruh yang signifikan terhadap kinerja, seperti penelitian yang dilakukan oleh Masuci (2010) menyatakan bahwa gaya kepemimpinan mempengaruhi kinerja sebesar 20,6\%. Kemudian, penelitian yang dilakukan oleh Endrawati (2017) menyatakan bahwa pelatihan berpengaruh signifikan sebesar 21,9\% terhadap kinerja.

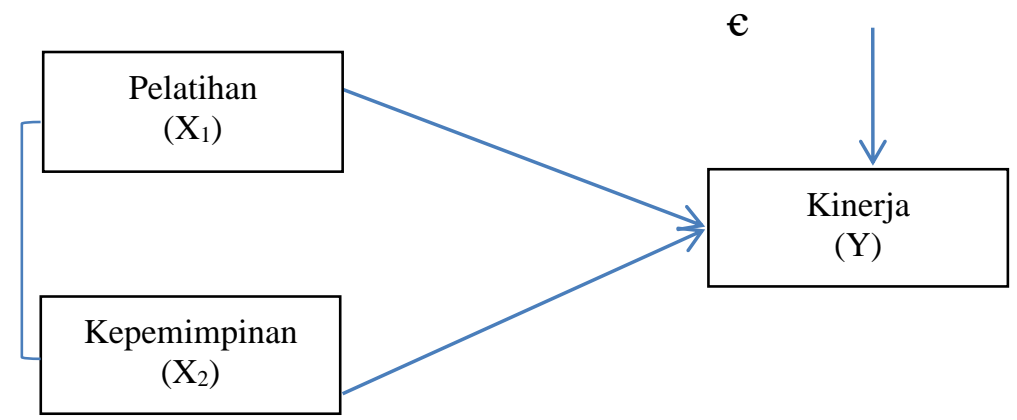

Gambar 1. Kerangka Berpikir 
Dalam penelitian ini yang menjadi variabel bebasnya $(\mathrm{X})$ adalah Pelatihan $\left(\mathrm{X}_{1}\right)$ dan Kepemimpinan $\left(\mathrm{X}_{2}\right)$, sedangkan variabel terikatnya $(\mathrm{Y})$ adalah Kinerja UKM. Pengujian hipotesis dari penelitian ini adalah untuk mengetahui ada tidaknya hubungan dan pengaruh antara variabel bebas $\left(\mathrm{X}_{1}\right.$ dan $\left.\mathrm{X}_{2}\right)$ terhadap variabel terikat $(\mathrm{Y})$ baik secara parsial maupun simultan.

\section{METODE PENELITIAN}

Penelitian ini menggunakan pendekatan kuantitatif. Penelitian kuantitatif adalah penelitian yang didasarkan pada data kuantitattif dimana data kuantitatif adalah data yang berbentuk angka atau bilangan. (Suliyanto, 2018). Penelitian ini dilakukan untuk mengetahui besarnya pengaruh pelatihan dan kepemimpinan terhadap kinerja UKM di Kabupaten Tegal selama masa pandemi covid-19. Data penelitian ini bersumber pada data primer dan data sekunder. Teknik pengumpulan data dilakukan melalui observasi, wawancara, dan kuesioner.

Populasi penelitian ini adalah pelaku UKM yang ada di Kab. Tegal. Untuk menentukan ukuran sampel, peneliti menggunakan Rumus Slovin sebagai berikut :

$$
\mathrm{n}=\frac{\mathrm{N}}{1+\mathrm{Nd}^{2}}
$$

Dimana :

$\mathrm{n}=$ ukuran sampel minimal

$\mathrm{N}=$ ukuran populasi

$\mathrm{d}=$ toleransi kesalahan (sampling error)

(Suliyanto, 2018)

Berdasarkan data dari Badan Pusat Statistik Kabupaten Tegal, jumlah UKM di Kabupten Tegal adalah 140.042 UKM. Sehingga jika dihitung menggunakan rumus Slovin di atas, total ukuran sampel dalam penelitian ini adalah 100 UKM.

Metode analisis data yang digunakan dalam penelitian ini adalah analisis jalur (path analysis).

\section{HASIL DAN PEMBAHASAN}

Salah satu misi Kabupaten Tegal adalah membangun perekonomian rakyat yang kokoh, maju, berkeadilan, dan berkelanjutan. Sebenarnya Kabupaten Tegal mempunyai potensi usaha yang cukup besar, namun adanya pandemi covid-19 sedikit memukul perekonomian masyarakat Kabupaten Tegal, khususnya untuk pelaku UKM. Untuk 
mendorong masyarakat tetap produktif selama pandemi covid-19 ini, Pemerintah Daerah Kab. Tegal tetap berinovasi dengan membuat berbagai kebijakan perlindungan dan pemulihan ekonomi bagi UKM terutama yang terdampak pandemi virus corona ini, diantaranya dengan mengeluarkan Surat Edaran Sekda No. 515/1674/2020 tanggal 9 April 2020 perihal himbauan kepada ASN di lingkungan Pemerintah Kabupaten Tegal untuk membeli produk UMKM mulai pejabat eselon 1 rata-rata $R p 100.000$,- atau minimal Rp 25.000,- per bulan. Kemudian kebijakan lain dikeluarkan melalui surat No. 050/677/2020 tanggal 1 April 2020 perihal penangguhan angsuran pinjaman yang ditujukan kepada perbankan tentang relaksasi kredit bagi UMKM guna memberikan insentif ekonomi bagi pelaku UMKM dan informal. Harapannya mereka akan dapat tetap produktif sekaligus terhindar dari melakukan pemutusan hubungan kerja (PHK) kepada karyawannya. (www.tegalkab.go.id).

Berdasarkan data dari Badan Pusat Statistik Kabupaten Tegal, jumlah industri kecil dan menengah, industri besar/ sedang, dan jumlah pengusaha kecil, menengah, dan besar yang ada di Kabupaten Tegal adalah 140.042 UKM. Jumlah tersebut terbagi dalam 17 jenis bidang usaha seperti kerajinan, logam, dan industri lainnya, sementara itu untuk kerajinan dan jenis olahan ada sekitar 26 ribu UKM.

Dari hasil penelitian, diperoleh data bahwa kepemimpinan UKM di Kabupaten Tegal secara umum sudah cukup baik, pimpinan memberikan dorongan kepada karyawan (87\%), menciptakan kondisi yang kondusif (91\%), menggunakan nilai etika yang baik dalam membina karyawan (80\%), dan memberikan kepercayaan kepada karyawan $(78 \%)$. Namun demikian, untuk pengetahuan mengenai visi misi, struktur organisasi, sasaran, tujuan UKM masih banyak yang belum mengetahui $(56,8 \%)$.

Adanya pandemi covid-19 ini sudah mengubah pola bisnis termasuk bisnis UKM, yaitu dengan pemanfaatan media digital untuk promosi dan penjualan untuk melaksanakan social distancing. Namun, banyak dari pelaku UKM di Kabupaten Tegal yang ternyata belum memahami atau menguasai media digital ini, sehingga UKM ini lah yang kemudian mengalami penurunan penjualan yang lebih besar dibandingkan pelaku UKM yang sudah menguasai dan mengaplikasikan media digital. Adanya pelatihan dirasa akan sangat membantu pelaku UKM untuk dapat bertahan atau meningkatkan usahanya. Dari hasil kuesioner diperoleh data bahwa pelatihan dan branchmarking ke UKM lain yang lebih maju dapat meningkatkan keterampilan dan 
pengetahuan pelaku UKM (80\%), sedangkan latar belakang pendidikan kurang berpengaruh terhadap pengetahuan dan keterampilan pelaku UKM $(53,8 \%)$.

Salah satu tolok ukur dari kinerja usaha adalah meningkatnyan omset yang diperoleh. Pelaku UKM harus terus mengembangkan usahanya dengan cara diantaranya memperbaiki standar dan kualitas produk serta layanan kepada para pelanggannya. Kemudian, karena adanya pergeseran pasar dari offline menjadi online, maka pelaku UKM pun harus dapat menyesuaikan diri untuk ikut dalam pemasaran secara digital atau online. Berdasarkan hasil penelitian, meskipun sebagian besar UKM di Kabupaten Tegal mengalami penurunan omset dan penghasilan, ada sekitar 58,2\% UKM yang tetap bertahan dan meningkat omset penjualannya selama pandemi covid-19 ini. misalnya UKM sarung goyor dan batik tulis tegalan yang tetap dapat mengekspor produknya karena memang sudah mempunyai pasar di luar negeri.

Hasil analisis data yang diperoleh dengan menggunakan SPSS 22.0 adalah sebagai berikut:

\section{Analisis Regresi}

Untuk melihat pengaruh variabel kepemimpinan dan pelatihan terhadap kinerja UKM secara gabungan atau simultan, dapat dilihat dari hasil model summary di bawah:

Tabel 1. Analisis Regresi

Model Summary

\begin{tabular}{|l|r|r|r|c|}
\hline Model & R & R Square & $\begin{array}{c}\text { Adjusted R } \\
\text { Square }\end{array}$ & $\begin{array}{c}\text { Std. Error of the } \\
\text { Estimate }\end{array}$ \\
\hline 1 &, $900^{\mathrm{a}}$ &, 810 &, 806 & 2,87944 \\
\hline
\end{tabular}

a. Predictors: (Constant), Pelatihan, Kepemimpinan Sumber: Hasil olah data SPSS 22.0

Berdasarkan hasil perhitungan di atas, besarnya angka $\mathrm{R}$ square $\left(\mathrm{r}^{2}\right)$ adalah 0,810 , angka tersebut digunakan untuk melihat besarnya pengaruh kepemimpinan dan pelatihan terhadap kinerja UKM secara simultan dengan cara menghitung koefisien determinasi (KD) dengan menggunakan rumus:

$$
\begin{aligned}
\mathrm{KD} & =\mathrm{r}^{2} \times 100 \% \\
\mathrm{KD} & =0,810 \times 100 \% \\
\mathrm{KD} & =81,0 \%
\end{aligned}
$$

Angka tersebut mempunyai makna bahwa pengaruh kepemimpinan dan pelatihan secara simultan terhadap kinerja UKM adalah $81 \%$ sedangkan sisanya sebesar $19 \%$ dipengaruhi oleh faktor lain. 
Untuk mengetahui apakah model regresi di atas sudah benar atau belum maka diperlukan uji hipotesis. Uji hipotesis dilakukan dengan membandingkan besarnya angka taraf signifikansi (sig) penelitian dengan taraf signifikansi sebesar 0,05 sebagaimana dapat dilihat pada tabel berikut:

Tabel 2. Analisis Regresi Simultan

ANOVA

\begin{tabular}{|ll|r|r|r|r|r|}
\hline Model & & Sum of Squares & df & Mean Square & F & Sig. \\
\hline 1 & Regression & 3424,744 & 2 & 1712,372 & 206,529 &, $000^{\mathrm{b}}$ \\
& Residual & 804,246 & 97 & 8,291 & & \\
& Total & 4228,990 & 99 & & & \\
\hline
\end{tabular}

a. Dependent Variable: Kinerja UKM

b. Predictors: (Constant), Pelatihan, Kepemimpinan

Sumber: Hasil Olah Data SPSS 22.0

Hipotesisnya adalah :

H0 : Tidak ada hubungan linear antara kepemimpinan dan pelatihan dengan kinerja UKM

H1 : Ada hubungan linear antara kepemimpinan dan pelatihan dengan kinerja UKM

Kriteria:

Jika sig penelitian $<0,01$ maka $\mathrm{H} 0$ ditolak dan $\mathrm{H} 1$ diterima

Jika sig penelitian > 0,01 maka H0 diterima dan $\mathrm{H} 1$ ditolak

Berdasarkan hasil perhitungan di atas, diketahui angka signifikansinya adalah 0,000< 0,01, maka model dinyatakan cocok atau fit, kemudian H0 ditolak dan H1 diterima, artinya terdapat hubungan linear antara kepemimpinan dan pelatihan dengan kinerja UKM.

Untuk melihat pengaruh variabel kepemimpinan dan pelatihan secara sendirisendiri atau parsial dapat dilihat dari hasil perhitungan di bawah ini:

Tabel 3. Analisis Regresi Parsial

Coefficients $^{\mathrm{a}}$

\begin{tabular}{|c|c|c|c|c|c|c|}
\hline \multirow{2}{*}{\multicolumn{2}{|c|}{ Model }} & \multicolumn{2}{|c|}{ Unstandardized Coefficients } & \multirow{2}{*}{$\begin{array}{c}\begin{array}{c}\text { Standardized } \\
\text { Coefficients }\end{array} \\
\text { Beta }\end{array}$} & \multirow[b]{2}{*}{$\mathrm{t}$} & \multirow[b]{2}{*}{ Sig. } \\
\hline & & $\mathrm{B}$ & Std. Error & & & \\
\hline \multirow[t]{3}{*}{1} & (Constant) & $-28,116$ & 4,324 & & $-6,503$ &, 000 \\
\hline & Kepemimpinan &, 816 &, 148 & ,327 & 5,499 & ,000 \\
\hline & Pelatihan & 2,236 & ,205 & ,648 & 10,889 &, 000 \\
\hline
\end{tabular}

a. Dependent Variable: Kinerja UKM

Sumber: Hasil Olah Data SPSS 22.0

Berdasarkan hasil perhitungan di atas dapat diketahui dari angka Beta atau Standardized

Coefficients bahwa pengaruh variabel kepemimpinan terhadap kinerja UKM adalah 
0,327 atau 32,7\% sedangkan pengaruh variabel pelatihan terhadap kinerja UKM adalah 0,648 atau $64,8 \%$.

\section{Analisis Korelasi}

Korelasi antara kepemimpinan, pelatihan, dan kinerja UKM dapat dilihat dari tabel berikut:

Tabel 4. Analisis Korelasi

Correlations

\begin{tabular}{|ll|r|r|}
\hline & \multicolumn{1}{|c|}{ Tepemimpinan } & \multicolumn{1}{|c|}{ Pelatihan } \\
\hline Kepemimpinan & Pearson Correlation & 1 &, $668^{* *}$ \\
& Sig. (2-tailed) & &, 000 \\
& $\mathrm{~N}$ & 100 & 100 \\
\hline Pelatihan & Pearson Correlation &, $668^{* *}$ & 1 \\
& Sig. (2-tailed) &, 000 & 100 \\
\hline
\end{tabular}

Correlation is significant at the 0.01 level (2-tailed)

Sumber: Hasil Olah Data SPSS 22.0

Penafsiran angka korelasi, digunakan kriteria sebagai berikut (Sarwono, 2007):

- $\quad 0-0,25 \quad$ : korelasi sangat lemah

- $0,25-0,5$ : korelasi cukup kuat

- $0,5-0,75 \quad$ : korelasi kuat

- $\quad 0,75-1 \quad$ : korelasi sangat kuat

Berdasarkan hasil perhitungan diketahui bahwa korelasi antara kepemimpinan dengan pelatihan adalah 0,668 dengan angka signifikansi $0,00<0,01$, maka sesuai dengan kriteria di atas korelasinya adalah kuat dan signifikan.

3. Diagram Jalur

Berdasarkan hasil analisis di atas maka diagram jalurnya dapat digambarkan sebagai berikut :

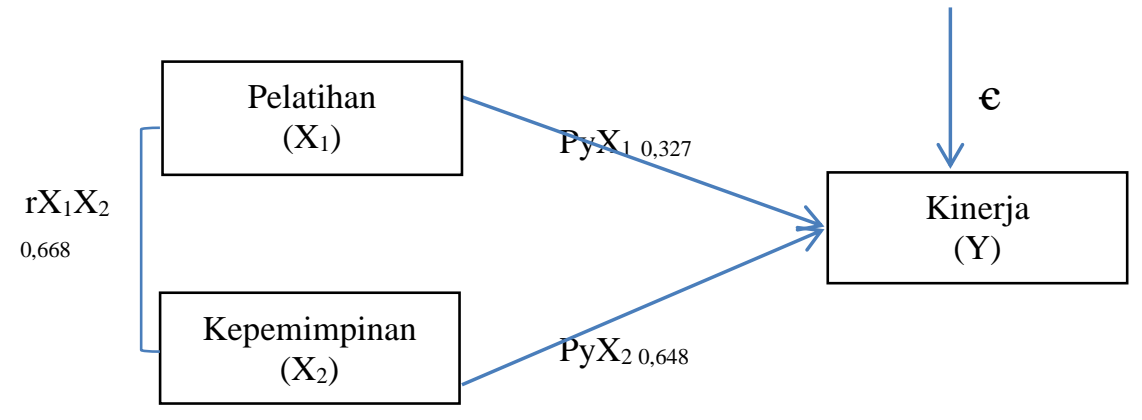

Gambar 2. Diagram Jalur

Persamaan struktural berdasarkan diagram jalur di atas adalah sebagai berikut:

$Y=0,327 X_{1}+0,648 X_{2}+\epsilon$ 


\section{E. SIMPULAN}

Berdasarkan hasil observasi penelitian diperoleh simpulan bahwa selama pandemi covid-19 memang kinerja UKM secara umum mengalami penurunan meskipun ada beberapa UKM khususnya di Kabupaten Tegal yang kinerjanya justru meningkat. Pemerintah Daerah Kabupaten Tegal dalam masa pandemi sudah berusaha memberikan fasilitas untuk para pelaku UKM supaya kegiatan ekonomi tetap berjalan dengan membuat Surat Edaran mengenai anjuran bagi para Aparatur Sipil Negara (ASN) untuk membeli produk UKM Kabupaten dengan minimal nominal tertentu, dan mengenai keringanan dalam hal pembayaran pinjaman.

Berdasarkan hasil analisis penelitian, kepemimpinan dan pelatihan memberikan pengaruh secara simultan sebesar $81 \%$ terhadap kinerja UKM di Kabupaten Tegal sisanya sebesar 19\% dipengaruhi oleh variabel lain yang tidak diteliti. Sedangkan secara parsial kepemimpinan memberikan pengaruh sebesar 32\% dan pelatihan memberikan pengaruh sebesar 64,8\% terhadap kinerja UKM khususnya di Kabupaten Tegal.

\section{DAFTAR PUSTAKA}

Gibson, J. L., Ivancevich, J. M., Donelly, J. H., \& Konopaske, J. M. (2003). Organization: Behavior, Struc-ture, Processes. New York: The McGraw-Hill Companies Inc.

Masuci, R. (2010, Juli). Analisis Pengaruh Lingkungan dan Gaya Kepemimpinan Wanita dalam Membangun Orientasi Kewirausahaan untuk Meningkatkan Kinerja Bisnis UKM. Jurnal Bisnis Strategi, Vol. 19 No. 1, 71-92.

Nurani, H., Dwiana, E., \& Eti, E. (2013). Pengaruh Kepemimpinan, Motivasi, dan Penggunaan Informasi terhadap Kinerja Pengambilan Keputusan dan Dampaknya terhadap Kinerja Perusahaan. Sosiohumaniora, 15 No.3, 261-271.

Nurani, Heni Elis Dwiana Euie Eti. (2013). Pengaruh Kepemimpinan, Motivasi, dan Penggunaan Informasi terhadap Kinerja Pengambilan Keputusan dan Dampaknya terhadao Kinerja Perusahaan. Sosiohumaniora, Vol. 15 No. 3, 261271.

Robbins, S. P., \& Judge, T. A. (2017). Perilaku Organisasi Organizational Behavior (Edisi 16 ed.). (R. Saraswati, \& F. Sirait, Trans.) Jakarta: Penerbit Salemba Empat.

Sarwono, J. (2007). Analisis Jalur untuk Riset Bisnis dengan SPSS (Edisi I ed.). Yogyakarta: Penerbit Andi. 
Suliyanto. (2018). Metode Penelitian Bisnis untuk Skripsi, Thesis, dan Disertasi. Yogyakarta: CV. Andi Offset.

Tambunan, T. T. (2015). Perekonomian Indonesia. (R. Sikumbang, Ed.) Bogor: Penerbit Ghalia Indonesia.

Tjiptono, F., \& Dian, A. (2001). Total Quality Management (Revisi ed.). Yogyakarta: Penerbit Andi.

Yukl, G. A. (2005). Leadership in Organizations. New Jersey, Englewood Cliffs: Prentice-Hall. Inc. 